\title{
EFFICIENCY OF THE BITTERLICH POINT SAMPLING AND THE METHOD OF FIXED AREA SAMPLING WITH STRUCTURAL VARIATIONS IN Pinus taeda PLANTATIONS
}

\author{
João Paulo Druszcz ${ }^{1 *}$, Sebastião do Amaral Machado ${ }^{2}$, Nelson Yoshihiro Nakajima ${ }^{2}$, \\ Nelson Carlos Rosot ${ }^{2}$, Roberto Tuyoshi Hosokawa ${ }^{2}$ \\ ${ }^{1 *}$ Universidade Federal do Paraná, Programa de Pós-Graduação em Engenharia Florestal, Curitiba, PR, Brasil - \\ jpaulorz@yahoo.com.br \\ ${ }^{2}$ Universidade Federal do Paraná, Departamento de Ciências Florestais, Curitiba, PR, Brasil - samachado@ufpr.br; \\ nelson.nakajima@ufpr.br; ncrosot@ufpr.br; rth@japan.org.br \\ Recebido para publicação: 14/02/2014 - Aceito para publicação: 17/03/2015
}

\begin{abstract}
This study aimed to compare two methods of sampling, one is the method of variable area represented by the Bitterlich point (PB) sampling and the other is the method of fixed area represented by circular plots (PC) with structural variation, the cross sampling cluster (CC) and the line sampling cluster (CL). Precision and efficiency in estimation of the variables mean DBH $(\mathrm{cm})$, number of trees $(\mathrm{N} / \mathrm{ha})$, basal area $\left(\mathrm{m}^{2} / \mathrm{ha}\right)$ and total volume $\left(\mathrm{m}^{3} / 3\right)$ in three plantation conditions of Pinus taeda L., located in the city of Carambeí, Paraná, were assessed. In simultaneous analysis of the three conditions to estimate the mean DBH and number of trees per hectare variables, the sampling method of fixed area with Circular Plot (PC) was the most accurate and efficient. The Bitterlich point sampling method (PB) was more accurate and efficient for the estimation of basal area and total volume variables. The two structures of sampling method of the fixed area with Cross Cluster (CC) and with Line Cluster (CL) demonstrated good results being the line cluster superior to the cross cluster. Keywords: Relative efficiency; precision; reforestation.
\end{abstract}

\section{Resumo}

Eficiência do método de amostragem de Bitterlich e de área fixa com variações estruturais em plantações de Pinus taeda. O estudo visou comparar dois métodos de amostragem, sendo eles o de área variável, o qual foi representado pelo método Ponto de Bitterlich (PB) e o de área fixa, representado pela Parcela Circular (PC) e as variações estruturais em Conglomerado em Cruz (CC) e Conglomerado em Linha (CL) com subunidades circulares. Foram avaliadas a precisão e eficiência para a estimativa da variável DAP médio $(\mathrm{cm})$, número de árvores $(\mathrm{N} / \mathrm{ha})$, área basal $\left(\mathrm{m}^{2} / \mathrm{ha}\right)$ e volume total $\left(\mathrm{m}^{3} / \mathrm{ha}\right)$, em três condições de plantações, localizadas no município de Carambeí, PR. Na análise simultânea das três condições para a estimativa da variável DAP médio $(\mathrm{cm})$ e número de árvores $(\mathrm{N} / \mathrm{ha})$, o método de área fixa com Parcela Circular (PC) foi o mais preciso e eficiente. Para a estimativa da variável área basal $\left(\mathrm{m}^{2} / \mathrm{ha}\right)$ e volume total $\left(\mathrm{m}^{3} / \mathrm{ha}\right)$, o método de área variável Ponto de Bitterlich foi mais preciso e eficiente. As duas estruturas do método de área fixa, utilizando-se o Conglomerado em Cruz (CC) e o Conglomerado em Linha (CL) apresentaram resultados precisos e eficientes, entretanto, o CL foi superior ao CC.

Palavras-chave: Eficiência relativa; precisão; reflorestamento.

\section{INTRODUCTION}

Being Brazil a leader in the international forest sector demonstrates how fast was its development in the last 50 years, with highly competitive private companies in the national scenery, not forgetting state bodies bound to this area, which demand accurate information on matters of interest about the forest, important for management plans and forest planning (MELLO, 2004).

It is common knowledge that starting from forest inventory, information on forest attributes are obtained, together with quantitative and qualitative information which, according to Nakajima et al. (1988), are the basic information to assist management and planning of forest production. Again,

FLORESTA, Curitiba, PR, v. 45, n. 3, p. 523 - 534, jul. / set. 2015.

Druszcz, J. P. et al.

ISSN eletrônico 1982-4688 / ISSN impresso 0015-3826 
according to the same authors, inventory data may be obtained by field measurements or by means of air photography, satellite images, laser images and others. However, despite alternative technologies, forest inventory by means of sampling unities in field is still the most used. In the forest sector, every company uses its own sampling method, which many times results from experience of the forest managers in function of the information desired from the forest, which are always, or at least should be, depending on the final destination of the forest itself (product).

Like in others fields of knowledge, which are always evolving and every time more demanding of accurate information in cheaper ways, in the forest sector could not be different. Optimization of a forest inventory depends on the efficiency of the chosen sampling method. According to Nakajima et al. (1998), efficiency of the different sampling methods (type, shape and size of the sampling unities) varies according with the type of forest (planted or natural), with forest condition and topography of the studied area. According to Nakajima (1997), adjustment of the sampling method to forest conditions and topography allows more precision with the same sampling effort in estimation of the variables of interest and consequently, a time reduction, resulting in cost reduction.

Thus, considering the cited points, it is clear the importance of this study aiming to compare precision and efficiency between the variable area sampling method, PB, and the fixed area sampling method with PC, CC and CL. These methods were applied in a forest inventory, using the same sampling units, to estimate mean DBH $(\mathrm{cm})$, number of trees $(\mathrm{N} / \mathrm{ha})$, basal area $\left(\mathrm{m}^{2} / \mathrm{ha}\right)$ and total volume $\left(\mathrm{m}^{3} / \mathrm{ha}\right)$, in Pinus taeda L. plantations, always aiming to reduction of sampling times, which will consequently reduce the operational costs.

\section{MATERIAL AND METHODS}

\section{Study area}

The area is located in the region of Ponta Grossa, State of Paraná. Geographical coordinates of the location are $24^{\circ} 04^{\prime} 44^{\prime \prime}$ south latitude and $50^{\circ} 05^{\prime} 49^{\prime \prime}$ west latitude. Climate is $\mathrm{Cfb}$ according to Köppen's classification, that is to say subtropical humid climate, mesothermal, with fresh summers, severe and frequent frosts and without dry season, with annual rainfall of $1400 \mathrm{~mm}$ distributed throughout the year. Temperature in the coldest months is lower than $18{ }^{\circ} \mathrm{C}$, while the annual average temperature of the hottest months is above $22^{\circ} \mathrm{C}$ (BOGNOLA et al., 2002).

Forest stands used in this study are formed by Pinus taeda L., not thinned, spaced $2.00 \mathrm{~m} \mathrm{x}$ $2.50 \mathrm{~m}$. Sampling units were located in three different stands, named condition 1, 2 and 3. Condition 1 has a planted area of 52.10 hectares, is 10 years old and its topographical mean inclination is $4^{\circ}$. Condition 2 has a planted area of 41.52 hectares, is 7 years old and its topographical mean inclination is $5.5^{\circ}$ and condition 3 has a panted area of $32.86 \mathrm{ha}$, is 9 years old and its topographical mean inclination is $6.5^{\circ}$. Total area of the three conditions was 126.48 ha.

\section{Experimental Design}

Experimental design was the randomized blocks with replications, in other words each topographical/age condition was considered as a block and, inside each block, 40 sampling points were randomly picked for the $\mathrm{PB}$ method and 10 sampling points for the PC fixed area method with $\mathrm{CC}$ and $\mathrm{CL}$. To control the experimental conditions, the two methods and their structural variations used the same sampling points.

Homoscedasticity or homogeneity of variance was verified in all conditions, followed by an analysis of variance (ANOVA) and finally, if necessary, the Tuckey HSD test of means was applied. All analyses were performed at 5\% level of probability. Software ASSISTAT, version 7.5 Beta was used to perform all tests (ASSISTAT, 2008).

\section{Hypsometric and volumetric equations used}

Total volumes and heights of the trees were estimated by the following equations used for each condition, generated with data of this survey.

\section{Condition 1}

Equation of the total volume, with bark, for individual tree (Schumacher-Hall logarithmic model) 


$$
\operatorname{Ln} \hat{\mathrm{V}}_{\mathrm{i}}=-10,60677097+1,957938764 . \ln \mathrm{DBH}_{\mathrm{i}}+1,190197992 . \ln \mathrm{H}_{\mathrm{i}}
$$

Hypsometric equation for total height (Curtis model)

$$
\operatorname{Ln} \hat{H}_{i}=3,484364+21,30533 \cdot 1 / \mathrm{DBH}+107,0489.1 / \mathrm{DBH}^{2}
$$

\section{Condition 2}

Equation of the total volume, with bark, for individual tree (Schumacher-Hall logarithmic model)

$$
\operatorname{Ln} \hat{\mathrm{V}}_{\mathrm{i}}=-9,678855718+1,961111183 . \ln \mathrm{DBH}_{\mathrm{i}}+0,825826416 . \ln \mathrm{H}_{\mathrm{i}}
$$

Hypsometric equation for total height (Ogawa model)

$$
1 / \hat{\mathrm{H}}_{\mathrm{i}}=0,05204485+0,800028.1 / \mathrm{DBH}_{\mathrm{i}}
$$

\section{Condition 3}

Equation of the total volume, with bark, for individual tree (Schumacher-Hall logarithmic model)

$$
\operatorname{Ln} \hat{\mathrm{V}}_{\mathrm{i}}=-9.584241626+1.908064397 . \ln \mathrm{DBH}+0.863903449 . \ln \mathrm{H}_{\mathrm{i}}
$$

Hypsometric equation for total height (Trorey model)

$$
\hat{\mathrm{H}}_{\mathrm{i}}=9.81649817-0.06224807 . \mathrm{DBH}+0.00778248 . \mathrm{DBH}^{2}
$$

\section{PB Sampling method}

In this study was applied the basal area factor two (BAF 2) because, using BAF 3 or 4 , few trees would be selected per sampling point and consequently sampling precision would be reduced. With BAF 1 , on the contrary, many trees would be selected, making work on field difficult. Data were collected using a Bitterlich Relascope.

Equations used to estimate variables were, according to Nishizawa (1972):

$$
\begin{array}{ll}
d m=\frac{\sum_{i=1}^{n}\left(\frac{d_{i}}{g_{i}}\right)}{\sum_{i=1}^{n}\left(\frac{1}{g_{i}}\right)} & N=k \sum_{i=1}^{n}\left(\frac{1}{g_{i}}\right) \\
G=k n & V=k \sum_{i=1}^{n}\left(\frac{v_{i}}{g_{i}}\right)
\end{array}
$$

where: $\quad d m=$ mean diameter $(\mathrm{cm}) ; N=$ number of trees per hectare; $G=$ basal area per hectare $\left(\mathrm{m}^{2} / \mathrm{ha}\right)$; $V=$ volume per hectare $\left(\mathrm{m}^{3} / \mathrm{ha}\right) ; k=$ basal area factor $(\mathrm{k}=2) ; n=$ number of selected trees per sampling point; $d_{i}=$ diameter of "i" selected tree $(\mathrm{cm}) ; g_{i}=$ area of the transverse section of "i" selected tree $v_{i}=$ Volume of the "i" selected tree $\left(\mathrm{m}^{3}\right)$.

\section{Fixed area sampling method with $\mathrm{PC}$}

Formulas used to estimate variables were, according to Nishizawa (1972):

$$
d m=\frac{\sum_{i=1}^{n} d_{i}}{n} \quad N=\frac{n}{a}
$$




$$
G=\frac{\sum_{i=1}^{n} g_{i}}{a}
$$

$$
V=\frac{\sum_{i=1}^{n} v_{i}}{a}
$$

where: $\quad a=$ area of the circular plot (ha).

\section{Sampling method with $\mathrm{CC}$ and $\mathrm{CL}$}

In this study, four sampling sub-units with different areas were used. This is to say that for each condition a radius was determined. In condition 1, radius of the sampling sub-unity was $6.75 \mathrm{~m}$, corresponding to an area of $143.14 \mathrm{~m}^{2}$ or 0.0143 ha. For condition 2, radius of the sampling sub-unity was $5.65 \mathrm{~m}$, corresponding to an area of $100.29 \mathrm{~m}^{2}$ or 0.01 ha and for condition 3 , radius of the sampling subunity was $5.60 \mathrm{~m}$, corresponding to an area of $98.52 \mathrm{~m}^{2}$ or 0.0099 ha. Distance between centers of the sub-unities was calculated fixing a distance of $10 \mathrm{~m}$ between limits of the sub-unities plus dimension of radiuses, which, in the above mentioned conditions, gave a distance between centers of $23.50 \mathrm{~m}, 21.3 \mathrm{~m}$ and $21.21 \mathrm{~m}$. (2008):

Formulas used to estimate variables were suggested by Queiroz (1998), and modified by Druszcz

$$
\begin{aligned}
& \overline{d_{i j}}=\frac{\sum_{k=1}^{n_{i j k}} d_{i j k}}{n_{i j k}} \quad d m=\frac{\sum_{i=1}^{n} \sum_{j=1}^{M} \overline{d_{i j}}}{n M} \\
& N A=\left(\frac{\sum_{i=1}^{n} \sum_{j=1}^{M} n_{i j}}{n . M}\right) \frac{1}{s} \quad G=\frac{\sum_{i=1}^{n} \sum_{j=1}^{M}\left(\sum_{k=1}^{n i j k} g i j k\right)}{n M} \frac{1}{s} \\
& V=\frac{\sum_{i=1}^{n} \sum_{j=1}^{M}\left(\sum_{k=1}^{n i j k} v i j k\right)}{n M} \frac{1}{S}
\end{aligned}
$$

where: $n=$ number of primary units or sampled clusters; $M=$ number of sub-unities forming each cluster; ${ }_{d m}=$ mean diameter of the cluster $(\mathrm{cm}) ; N A=$ number of trees per hectare; $G=$ basal area per hectare $\left(\mathrm{m}^{2} / \mathrm{ha}\right) ; V=$ volume per hectare $\left(\mathrm{m}^{3} / \mathrm{ha}\right) ; \overline{d_{i j}}=$ mean diameter of the selected trees in " $\mathrm{j}$ " sub-unity of " $\mathrm{i}$ " cluster; $n_{i j k}=$ number of " $\mathrm{k}$ " trees selected in " $\mathrm{j}$ " sub-unity in " $\mathrm{i}$ " cluster; $g_{i j k}=$ basal area of "k" tree selected in "j" sub-unity in "i " cluster; $v_{i j k}=$ volume of "k" tree selected in " $\mathrm{j}$ " sub-unity in " $\mathrm{i}$ " cluster; $s=$ area of the circular sub-unity (ha).

\section{Method of the Relative Efficiency (RE)} method.

To calculate the relative efficiency, all estimated variables were considered in each sampling

Freese (1962) considers the average measuring times in each method and the obtained coefficients of variation. In the case of this work; the method and/or structure presenting the higher relative efficiency value is the most efficient, calculated by the following formula:

$$
R E=\frac{1}{T_{i} C V^{2}}
$$

where: $R E=$ Relative Efficiency; $T_{i}=$ measuring time of the "i" sampling unit; $C V=$ coefficient of variation. 


\section{Statistical analyses}

Statistical analysis for PB and PC

For sampling with use of $\mathrm{PB}$ and $\mathrm{PC}$, statistical analyses were made using the following formulas, according to Péllico Netto and Brena (1997):

$$
\begin{array}{lc}
\bar{x}=\frac{\sum_{i=1}^{n}\left(x_{i}\right)}{n} & s_{x}^{2}=\frac{\sum_{i=1}^{n}\left(x_{i}-\bar{x}\right)^{2}}{n-1} \\
s_{x}=\sqrt{s_{x}^{2}} & s_{\bar{x}}= \pm \frac{s_{x}}{\sqrt{n}} \\
c v=\frac{s_{x}}{x} 100 & e r= \pm \frac{t s_{-}}{\bar{x}} 100 \\
i c=\bar{x} \pm t s_{\bar{x}} &
\end{array}
$$

where: $\bar{x}=$ mean of the variable $\mathrm{x} ; x_{i}=$ value of each variable $\mathrm{x} ; n=$ number of sampling units; $s^{2}=$ variance; $s=$ standard deviation; $s_{\bar{x}}=$ standard error; er = sampling error in percentage; $t=$ Student's tabular value, $\left(\mathrm{t}_{(39 ; 0.05)}=2,023\right), i c=$ Confidence interval.

$95 \%$.

Population was considered infinite, with max permissible error of $10 \%$ and confidence level of

Statistical analysis for CC and CL

For sampling with use of $\mathrm{CC}$ and CL, statistical analyses were made using the following formulas, according to Péllico Netto and Brena (1997):

$$
\begin{gathered}
-\sum_{x=\frac{\sum_{i=1}^{n}}{n} \sum_{j=1}^{M} X_{i j}}^{n M} \\
s_{x}^{2}=s_{e}^{2}+s_{d}^{2}=\sum_{j=1}^{M} \frac{X_{i j}}{M} \\
s_{d}^{2}=M Q_{\text {dentro }}=\frac{\sum_{i=1}^{n} \sum_{j=1}^{M}\left(X i_{j}-\bar{x}_{i}\right)^{2}}{n(M-1)} \\
s_{e}^{2}=\frac{M Q_{\text {entre }}-M Q_{\text {dentro }}}{M} \quad \text { where } M Q_{\text {entre }}=\frac{\sum_{i=1}^{n} M\left(\bar{x}_{i}-\bar{x}\right)^{2}}{n-1} \\
r=\frac{s_{e}^{2}}{s_{e}^{2}+s_{d}^{2}} \\
s=\sqrt{s_{e}^{2}+s_{d}^{2}} \\
s_{\bar{x}}=\sqrt{s_{\bar{x}}^{2}} \\
\quad i c= \pm t s_{\bar{x}}^{2}
\end{gathered}
$$


where: $\bar{x}=$ mean of population per sub-unity; $x_{i}=$ mean of sub-unities per cluster; $n=$ number of sampled clusters; $s_{x}^{2}=$ population variance per sub-unity; $s_{e}^{2}=$ variance between clusters; $s_{d}^{2}=$ variance inside the clusters; $Q M_{\text {entre }}=$ mean square between clusters; $Q M_{\text {dentro }}=$ mean square between sub-unities inside the clusters; $r=$ coefficient of correlation between clusters; $s_{x}^{2}=$ variance of the mean; $s=$ standard deviation; $s_{-}=$standard error; $c v=$ coefficient of variation; $e r$ $=$ sampling error in percentage; $t=$ Student's tabular value $\left(\mathrm{t}_{(09 ; 0.05)}=2,262\right), i c=$ confidence interval.

Population was considered infinite, being the maximum permissible error equal to $10 \%$, with $95 \%$ of confidence.

\section{RESULTS AND DISCUSSIONS}

DBHs of 9,443 trees were measured in 300 sampling units installed in an experimental area of 126.48 ha. On average, for each condition, were sampled 22, 19 and 18 trees per sampling unit, being this number a little smaller in all conditions for PB due to the adjustment difficulties of the FAB. Variation in the number of trees of a sampling unit was also influenced by mortality and defects of the forest stand.

\section{Estimation of the variables for both methods and their structural variations}

Table 1 resumes the estimated values of the variables mean DBH $(\mathrm{cm})$, number of trees $(\mathrm{N} / \mathrm{ha})$, basal area $\left(\mathrm{m}^{2} / \mathrm{ha}\right)$ and total volume $\left(\mathrm{m}^{3} / \mathrm{ha}\right)$ for each condition.

Table 1. Estimative of the variables mean DBH, number of trees, basal area and total volume per ha for the three evaluated conditions.

Tabela 1. Estimativa das variáveis DAP médio $(\mathrm{cm})$, número de árvores $(\mathrm{N} / \mathrm{ha})$, área basal $\left(\mathrm{m}^{2} / \mathrm{ha}\right)$ e volume total $\left(\mathrm{m}^{3} / \mathrm{ha}\right)$ para as três condições avaliadas.

\begin{tabular}{lcccc}
\hline Variables & PB & PC & CC & CL \\
\hline Mean DBH $(\mathrm{cm})$ & Condition 1 & & & \\
Mean number of trees (N/ha) & 17.1 & 16.6 & 16.5 & 16.5 \\
Mean basal area $\left(\mathrm{m}^{2} / \mathrm{ha}\right)$ & 1.723 & 1.619 & 1.600 & 1.638 \\
Mean volume $\left(\mathrm{m}^{3} / \mathrm{ha}\right)$ & 40.15 & 36.94 & 36.24 & 36.89 \\
\hline & 261.33 & 237.24 & 231.87 & 235.04 \\
\hline Mean DBH $(\mathrm{cm})$ & 15.9 & 16.0 & 16.0 & 16.1 \\
Mean number of trees (N/ha) & 1.768 & 1.924 & 1.865 & 1.895 \\
Mean basal area $\left(\mathrm{m}^{2} / \mathrm{ha}\right)$ & 35.65 & 40.15 & 38.90 & 39.72 \\
Mean volume $\left(\mathrm{m}^{3} / \mathrm{ha}\right)$ & 169.94 & 191.96 & 185.78 & 189.84 \\
\hline & Condition 2 & & & \\
\hline Mean DBH $\left(\mathrm{cm}^{2}\right)$ & 15.2 & 15.3 & 15.1 & 15.3 \\
Mean number of trees $(\mathrm{N} / \mathrm{ha})$ & 1.764 & 1.868 & 1.855 & 1.875 \\
Mean basal area $\left(\mathrm{m}^{2} / \mathrm{ha}\right)$ & 33.00 & 35.90 & 34.76 & 35.72 \\
Mean volume $\left(\mathrm{m}^{3} / \mathrm{ha}\right)$ & 176.44 & 192.56 & 185.88 & 191.17 \\
\hline
\end{tabular}

\section{Classification of methods and structures based on sampling error}

Classification of $\mathrm{PB}$ and fixed area with $\mathrm{PC}, \mathrm{CC}$ and $\mathrm{Cl}$ sampling methods, showing precision in estimation of the variables, is presented in table 2 .

\section{Simultaneous comparison of the three assessed conditions}

Variances of sampling errors and relative efficiency where homogeneous at 5\% level of error probability by Bartlett's test for all variables.

In ANOVA, both for sampling error and relative efficiency, test $\mathrm{F}$ for blocks was not significant, in other words blocks did not have influence in estimating the assessed variables, because they have similar effects. 
Table 2. Classification of the methods based on sampling error.

Tabela 2. Classificação dos métodos com base no erro de amostragem.

\begin{tabular}{|c|c|c|c|c|}
\hline \multirow{2}{*}{ Variables } & \multicolumn{4}{|c|}{ Classification / Method } \\
\hline & $1^{\text {st }}$ place & $2^{\text {nd }}$ place & $3^{\text {rd }}$ place & $4^{\text {th }}$ place \\
\hline \multicolumn{5}{|c|}{ Condtion 1} \\
\hline Mean DBH $(\mathrm{cm})$ & $\mathrm{PC}$ & $\mathrm{PB}$ & $\mathrm{CL}$ & $\mathrm{CC}$ \\
\hline Mean number of trees (N/ha) & $\mathrm{PC}$ & $\mathrm{CC} / \mathrm{CL}$ & $\mathrm{PB}$ & - \\
\hline Mean basal area $\left(\mathrm{m}^{2} / \mathrm{ha}\right)$ & PC & $\mathrm{PB}$ & $\mathrm{CL}$ & $\mathrm{CC}$ \\
\hline Mean volume $\left(\mathrm{m}^{3} / \mathrm{ha}\right)$ & $\mathrm{PC}$ & PB & $\mathrm{CL}$ & $\mathrm{CC}$ \\
\hline \multicolumn{5}{|c|}{ Condition 2} \\
\hline Mean DBH $(\mathrm{cm})$ & $\mathrm{PC}$ & $\mathrm{CL}$ & $\mathrm{PB}$ & $\mathrm{CC}$ \\
\hline Mean number of trees $(\mathrm{N} / \mathrm{ha})$ & $\mathrm{CL}$ & $\mathrm{PC}$ & $\mathrm{CC}$ & PB \\
\hline Mean basal area $\left(\mathrm{m}^{2} / \mathrm{ha}\right)$ & $\mathrm{CL}$ & $\mathrm{PB}$ & $\mathrm{CC}$ & $\mathrm{PC}$ \\
\hline Mean volume $\left(\mathrm{m}^{3} / \mathrm{ha}\right)$ & $\mathrm{PB}$ & $\mathrm{CL}$ & $\mathrm{PC}$ & $\mathrm{CC}$ \\
\hline \multicolumn{5}{|c|}{ Condition 3} \\
\hline Mean DBH $(\mathrm{cm})$ & $\mathrm{PC}$ & PB & CL & $\mathrm{CC}$ \\
\hline Mean number of trees $(\mathrm{N} / \mathrm{ha})$ & $\mathrm{PC}$ & $\mathrm{CL}$ & $\mathrm{CC}$ & PB \\
\hline Mean basal area $\left(\mathrm{m}^{2} / \mathrm{ha}\right)$ & PB & $\mathrm{PC}$ & $\mathrm{CL}$ & $\mathrm{CC}$ \\
\hline Mean volume (m³ $/ \mathrm{ha})$ & $\mathrm{PB}$ & $\mathrm{PC}$ & $\mathrm{CL}$ & $\mathrm{CC}$ \\
\hline
\end{tabular}

Analysis of variance of the mean DBH $(\mathrm{cm})$ showed that there were significant differences between at least one of the means of the treatments, both for sampling error and for relative efficiency and thus, to know which means were different, Tukey test was performed (Table 3). For sampling error, estimating the mean DBH $(\mathrm{cm})$, Tukey test demonstrated that there was no statistical difference between $\mathrm{CC}$ and $\mathrm{CL}$, being $\mathrm{CC}$ different from $\mathrm{PB}$ and PC. Between $\mathrm{CL}$ and $\mathrm{PB}$, and $\mathrm{PB}$ and $\mathrm{PC}$ there is no statistical difference, but there is difference between PC and CL. This analysis confirmed PC as the most accurate and indicated to estimate mean DBH $(\mathrm{cm})$. For relative efficiency, according to Tuckey test, the only ones showing differences are PC and CC. PC is the most efficient to estimate mean DBH $(\mathrm{cm})$, being this efficiency $36 \%$ higher, on average, than in other treatments.

Analysis of variance of the number of trees $(\mathrm{N} / \mathrm{ha}$ ) showed that there are significant differences for the means of treatments, both for sampling error and for relative efficiency, thus, to know which means were different, Tukey test was performed (Table 3). For sampling error, comes out that PB is statistically different from the others, being CC and CL not different between them, same as CL and PC. This result confirms that $\mathrm{PC}$ is the most accurate to estimate the number of trees (N/ha). Considering relative efficiency, it is verified that PC is statistically different from the others, which qualifies it as the most efficient to estimate the number of trees $(\mathrm{N} / \mathrm{ha})$, being this relative efficiency $25 \%$ higher than all other.

Considering basal area $\left(\mathrm{m}^{2} / \mathrm{ha}\right)$, analysis of variance for sampling error showed that there are no statistical differences between the means of treatments, making the Tukey Test un-necessary to distinguish the means. PB is the most accurate estimating this variable, according to sampling error showed in table 3. Analysis of variance of relative efficiency estimating basal area $\left(\mathrm{m}^{2} / \mathrm{ha}\right)$ showed that there are statistical differences between at least one of the means of treatments and, to verify which are the different means, a Test of Tukey was performed (Table 3). The test revealed that just PB and CC were statistically different between them, being PB the most efficient method to estimate basal area, being this efficiency 39\% bigger, on average, than the one of other. According to Nakajima (1997), being sampling probability in Bitterlich Point proportional to basal area, estimation of this variable is more efficient than in the fixed area method.

Considering the total volume $\left(\mathrm{m}^{3} / \mathrm{ha}\right)$, analysis of variance for sampling error showed that there are not statistical differences between means of treatments, making the Test of Tukey un-necessary. PB is the most accurate method to estimate this variable, according to the sampling error presented in table 3.in the analysis of variance of relative efficiency in estimation of total volume $\left(\mathrm{m}^{3} / \mathrm{ha}\right)$ there were statistical differences between means of treatments. When Tukey Test was performed, it revealed that only PB and CC were statistically different, with an average relative efficiency $43 \%$ higher than in other methods. Nakajima (1997) reported that PB method was the one that presented the smaller sampling error estimating the volume variable, fact confirmed in the results of this work. 
Considering sampling error of the mean DBH (cm), Nakajima et al. (1995), studying reforestation of Japanese cedar (Cryptomeria japonica D. Don), obtained similar results to this study. Yoshida (1991), studying reforestation of Japanese cedar (Cryptomeria japonica D. Don), obtained the following classification of sampling methods: Strand method, or fixed area method with Circular Plot (PC), followed by fixed area method with Concentric Circular Plot and by the Bitterlich Point method. Nakajima et al. (2011), in a comparative study between the in line cluster sampling method (Strand method) and the Concentric Circular Plot method in plantations of Pinus elliottii Engelm., in the municipality of Nova Campina, southern San Paolo state, concluded that the Concentric Circular Plot method was slightly superior to the in line cluster sampling method. However, there was no statistically significant difference between the two methods in the evaluation of this variable.

Table 3. Tukey test for the estimates of the variables.

Tabela 3. Teste de tukey para as estimativas das variáveis.

\begin{tabular}{|c|c|c|}
\hline Method/Structure & Sampling error & Relative efficiency \\
\hline \multicolumn{3}{|c|}{ Mean DBH $(\mathrm{cm})$} \\
\hline$\overline{\mathrm{PB}}$ & $2.34 \mathrm{bc}$ & $2.57 \mathrm{ab}$ \\
\hline PC & $1.81 \mathrm{c}$ & $4.02 \mathrm{a}$ \\
\hline $\mathrm{CC}$ & $3.06 \mathrm{a}$ & $2.43 \mathrm{~b}$ \\
\hline CL & $2.45 \mathrm{ab}$ & $2.69 \mathrm{ab}$ \\
\hline & $\mathrm{MG}=2.41 \mathrm{CV} \%=9.03 \mathrm{LSD}=0.62$ & $\mathrm{MG}=2.93 \mathrm{CV} \%=18.80 \mathrm{LSD}=1.56$ \\
\hline \multicolumn{3}{|c|}{ Number of trees (N/ha) } \\
\hline PB & $5.47 \mathrm{a}$ & $0.44 \mathrm{~b}$ \\
\hline $\mathrm{PC}$ & $2.20 \mathrm{c}$ & $1.04 \mathrm{a}$ \\
\hline $\mathrm{CC}$ & $3.69 \mathrm{~b}$ & $0.92 \mathrm{~b}$ \\
\hline $\mathrm{CL}$ & $2.93 \mathrm{bc}$ & $0.98 \mathrm{~b}$ \\
\hline & $\mathrm{MG}=3.57 \mathrm{CV} \%=13.05 \mathrm{LSD}=0.93$ & $\mathrm{MG}=1.33 \mathrm{CV} \%=48.74 \mathrm{LSD}=1.83$ \\
\hline \multicolumn{3}{|c|}{ Basal area $\left(\mathrm{m}^{2} / \mathrm{ha}\right)$} \\
\hline$\overline{\mathrm{PB}}$ & 3.20 & $1.31 \mathrm{a}$ \\
\hline PC & 3.56 & $1.04 \mathrm{ab}$ \\
\hline $\mathrm{CC}$ & 5.26 & $0.61 b$ \\
\hline CL & 4.38 & $0.75 \mathrm{ab}$ \\
\hline & & $\mathrm{MG}=0.93 \mathrm{CV} \%=25.56 \mathrm{LSD}=0.67$ \\
\hline \multicolumn{3}{|c|}{ Total volume $\left(\mathrm{m}^{3} / \mathrm{ha}\right)$} \\
\hline$\overline{\mathrm{PB}}$ & 3.41 & $1.18 \mathrm{a}$ \\
\hline PC & 3.97 & $0.84 \mathrm{ab}$ \\
\hline $\mathrm{CC}$ & 6.02 & $0.52 \mathrm{~b}$ \\
\hline $\mathrm{CL}$ & 5.10 & $0.64 \mathrm{ab}$ \\
\hline
\end{tabular}

MG: General mean; CV\%: Coefficient of variation in \%; LSD: Least Significant Difference.

Considering the variable number of trees (N/ha), Nakajima et al. $(1995,1996)$ obtained, in the conditions of Experimental Forests of Shiragadake and Takakuma, Japan, the following results: in first place the fixed area method with Circular Plot, followed by the fixed area method with Concentric Circular Plot and Strand. Couto et al. (1990) compare the Bitterlich method, using basal area factors of 2, 3 and 4, with the fixed area method to estimate the number of trees $(\mathrm{N} / \mathrm{ha})$ of a plain and an uneven area in plantations of Eucaliptus saligna Sm.. Authors concluded that the Bitterlich method accurately estimated the number of trees per hectare in both areas with the three basal area factors considered, however, they verified greater variances between the estimates obtained with the Bitterlich method than with the fixed area method. Nakajima et al. (2011) concluded that the in line cluster sampling method was slightly superior to the Concentric Circular Plot method, however, without statistically significant differences in estimation of the $\mathrm{N} / \mathrm{ha}$ variable.

Considering basal area $\left(\mathrm{m}^{2} / \mathrm{ha}\right)$, Loetsch et al. (1973) observed that, in the PB method, due to probability that sampling is proportional to the transverse section area of trees, basal area per hectare is 
much better estimated than in fixed area methods. Nakajima et al. $(1995,1996)$ obtained better estimate of basal area in the condition of the Shiragadake Experimental Forests (Mixed Forests) using the Bitterlich method, followed by fixed area method with Concentric Circular Plot, Strand method and fixed area method with Circular Plot. In Takakuma Experimental Forest reforestation conditions results were: fixed area method with Concentric Circular Plot, fixed area method with Circular Plot, or Bitterlich, and Strand. Nakajima et al. (2011), in a comparative study between the in line sampling method, or Strand method, and the Concentric Circular Plot sampling method in plantations of Pinus elliotti Engelm., in the municipality of Nova Campina, southern San Paolo state, concluded that the in line sampling method showed superiority to the Concentric Circular Plot method. There was statistical significant difference between the two methods in estimation of this variable.

Considering total volume ( $\left.\mathrm{m}^{3} / \mathrm{ha}\right)$, Nakajima et al. $(1995,1996)$ obtained better results in the Shiragadake Experimental Forest conditions (Mixed Forests), using the Bitterlich point sampling method, followed by the fixed area method with Concentric Circular Plot, Strand method and last the fixed area method with Circular Plot. In Takakuma Experimental Forest reforestation conditions, results were the following: fixed area method with Concentric Circular Plot, fixed area method with Circular Plot or Bitterlich and Strand. Yoshida (1991), also studying Japanese cedar reforestations, obtained the following results studying volume per hectare: Strand method, fixed area method with Circular Plot, Bitterlich method and fixed area method with Concentric Circular Plot. Mahrer and Vollenweider (1983), studying reforestations in Switzerland, obtained the following classifications: method of fixed area with Concentric Circular Plot, followed by the Strand method, Bitterlich method and fixed area method with Circular Plot. Nakajima et al. (2011), in a comparative study between the in line cluster sampling method and the Concentric Circular Plot sampling method in plantations of Pinus elliotti Engelm., concluded that the inline cluster sampling method showed to be superior to the Concentric Circular Plot, with statistically significant difference between them in estimation of the total volume.

Considering relative efficiency, Moscovich et al. (1999), in a study performed in a forest of Araucaria angustiolia (Bert.) O. Ktze., located in the municipality of São Francisco de Paula, RS, obtained for the variable number of trees $(\mathrm{N} / \mathrm{ha}$ ) the following classification in relative efficiency: Strand method, Prodan method, Fixed Area and Bitterlich method. Considering the basal area $\left(\mathrm{m}^{2} / \mathrm{ha}\right)$ and volume $\left(\mathrm{m}^{3} / \mathrm{ha}\right)$ variables, found the following classification of relative efficiency: Strand method, Bitterlich method, Prodan method and the Fixed Area method. Researchers Cesaro et al. (1994), estimating volume $\left(\mathrm{m}^{3} / \mathrm{ha}\right)$ in a Pinus sp. forest stand, verified higher efficiency of the Fixed Area method followed by the Bitterlich method and the Six Trees method.

\section{CONCLUSION}

Simultaneous analysis of the results of the three conditions studied in the forest inventory lead to the conclusion that:

- Estimating the mean DBH $(\mathrm{cm})$, the fixed area method with Circular Plot (PC) was the most accurate and efficient, followed by the Bitterlich method (PB) in accuracy and by the fixed area method with Line Cluster (CL) for efficiency, highlighting that there were no statistically significant differences between the methods, both for sampling error and for relative efficiency.

- Estimating the number of trees (N/ha), the fixed area method with Circular Plot (PC) was the most accurate and efficient, followed by the fixed area method with Line Cluster (CL), being the difference between fixed area method with Circular Plot (PC) and fixed area with Line Cluster (CL) statistically significant only for relative efficiency.

- Estimating the basal area $\left(\mathrm{m}^{2} / \mathrm{ha}\right)$, the Bitterlich point method (PB) was the most accurate and efficient, followed by the fixed area method with Circular Plot (PC), highlighting that there was no statistically significant difference between them, both for the sampling error and for relative efficiency.

- Estimating total volume $\left(\mathrm{m}^{2} / \mathrm{ha}\right)$, the Bitterlich point method (PB) was the most accurate and efficient, followed by the fixed area method with Circular Plot (PC), highlighting that there was no statistically significant difference between them, both for sampling error and for relative efficiency.

FLORESTA, Curitiba, PR, v. 45, n. 3, p. 523 - 534, jul. / set. 2015.

Druszcz, J. P. et al.

ISSN eletrônico 1982-4688 / ISSN impresso 0015-3826

DOI: $10.5380 /$ rf.v45i3.35410 


\section{REFERENCES}

BOGNOLA, I. POTTER, R. O.; CARVALHO, A. P.; FASOLO, P. J.; BHERING, S. B.; MARTARANO, L. G. Caracterização dos solos do município de Carambeí - PR. Boletim de Pesquisa e Desenvolvimento, Rio de Janeiro, 2002, 75 p.

CESARO, A.; ENGEL, O. A.; FINGER, C. O. G.; SCHNEIDER, P. R. Comparação dos métodos de amostragem de área fixa, relascopia e de seis árvores, quanto a eficiência, no inventário florestal de um povoamento de Pinus sp. Ciência Florestal, Santa Maria, v. 4, n. 1, p. 97 - 108, 1994.

COUTO, H. T. Z.; BASTOS, N. L. M.; LACERDA, J. S. A amostragem por pontos na estimativa da altura de árvores dominantes e número de árvores por hectare em povoamentos de Eucaliptus saligna. IPEF, Piracicapa, n. 43 - 44, p. 50 - 53, 1990.

DRUSZCZ, J. P. Comparação do método de Bitterlich com três variações estruturais do método de área fixa com unidades circulares em plantio de Pinus taeda L. 120 f. Dissertação (Mestrado em Manejo Florestal) - Universidade Federal do Paraná, Curitiba, 2008.

FREESE, F. Elementary forest sampling. Washington U.S. Forest Service, 1962, 91 p.

LOETSCH, F.; ZÖHRER, F.; HALLER, K. E. Forest inventory. $2^{\text {a }}$ ed. Munich: BLV Vellagsgesellschaft, 1973, $469 \mathrm{p}$.

MAHRER, F.; VOLLENWEIDER, C. National forest inventory. Swiss Federal Institute of Forestry Research, 1983, 26 p.

MELLO, J. M. Geoestatística aplicada ao inventário florestal. 122 f. Tese (Doutorado em Engenharia Florestal) - Escola Superior de Agricultura Luiz de Queiroz, Universidade de São Paulo, Piracicaba, 2004.

MOSCOVICH, F. A.; BRENA, B. A.; LONGHI, S. J. Comparação de diferentes métodos de amostragem, de área fixa e variável, em uma floresta de Araucaria angustifolia. Ciência Florestal, Santa Maria, v. 9, n. 1, p. 173 - 191, 1999.

NAKAJIMA, N. Y.; YOSHIDA, S.; IMANAGA, M. Comparison among four ground-survey methods as a continuous forest inventory system for forest management. J. Jpn. For. Soc. v. 77, n. 6, p. 573 - 580, 1995.

NAKAJIMA, N. Y.; YOSHIDA, S.; IMANAGA, M. Comparison of change estimation between four ground-survey methods for use in a continuous forest inventory system. J. For. Plann. v. 2, n. 2. p. 145 $150,1996$.

NAKAJIMA, N. Y. Comparison of four ground-survey methods when used as permanent samples in the continuous forest inventory for forest management. $91 \mathrm{f}$. Thesis ( $\mathrm{PhD}$ in Agricultural Sciences) Kagoshima University, Kagoshima, 1997.

NAKAJIMA, N. Y.; KIRCHNER, F. F.; SANQUETTA, C. R.; POSONSKI, M. Elaboração de um sistema de amostragem para estimativa de valores correntes e mudança/crescimento em reflorestamento de Pinus. Curitiba: CNPq/UFPR, 1998. 33 p.

NAKAJIMA, N. Y.; PÉLLICO NETTO, S.; DRUSZCZ, J. P.; YOSHITANI JUNIOR, M. Comparação da precisão entre os métodos de amostragem linha e parcela circular concêntrica em povoamentos de Pinus elliotti. Revista Acadêmica: Ciências Agrárias e Ambientais, Curitiba, v. 9, n. 2, p. 131 - 139, 2011.

NISHIZAWA, M. Forest mensuration. Tokyo: Nourinshuppan, 1972, 348 p.

PÉLLICO NETTO, S.; BRENA, D. Inventário florestal. Curitiba: Universidade Federal do Paraná, 1997, $316 \mathrm{p}$. 
QUEIROZ, W. T. Técnicas de amostragem em inventário florestal nos trópicos. Belém: FCAP, 1998, $147 \mathrm{p}$.

UNIVERSIDADE FEDERAL DE CAMPINA GRANDE. ASSISTAT, versão 7.5 (beta). Campina Grande - PB, 2008, http.//www.assistat.com.

YOSHIDA, S. Studies on the continuous forest inventory system: comparison of survey methods on the ground. The Bulletin of the Faculty of Agriculture, Kagoshima University, Japan, 1991.

FLORESTA, Curitiba, PR, v. 45, n. 3, p. 523 - 534, jul. / set. 2015. 
FLORESTA, Curitiba, PR, v. 45, n. 3, p. 523 - 534, jul. / set. 2015 Druszcz, J. P. et al. 